\title{
Status Sosial Ekonomi dan Kualitas Partai Politik dalam Meningkatkan Partisipasi Politik
}

\author{
MUHAMMAD YAHYA ARWIYAH \\ Institut Manajemen Telkom Bandung, Jl. Terusan Buahbatu Bandung 40257 \\ email: yahya_arwiyah@yahoo.co.id
}

\begin{abstract}
Voters in Bandung Regency is part of Indonesian people playing an important role in determining policy and organizing lawful lives considering Indonesia is a democratic nation based on constitutions. On other hand, the involvement of citizens in a political life general or regional election was not free from socio-economic status or background of in fact, political participation of citizens was not yet optimum because of the diversity of socio-economic status, the decrease in trust level of citizens forwards ideological line of tehe political parties, and role of paternalistic culture as well as the lack of political education carried on by the political parties.
\end{abstract}

Keywords: political paries, political participan, socio-economic status,

\begin{abstract}
Abstrak. Masyarakat pemilih di Kabupaten Bandung merupakan bagian dari rakyat Indonesia yang berperan penting dalam penentuan dan penyelenggaran kehidupan bernegara mengingat Indonesia sebagai negara demokrasi berdasarkan hukum. Namun, keterlibatan warga negara dalam kehidupan politik pada pemilihan umum ataupun kepala daerah tidak terlepas dari status sosial ekonomi dan kualitas partai. Kenyataannya, partisipasi politik warga negara belum optimal dengan keragaman status sosial ekonomi. Hal ini menyebabkan menurunnya tingkat kepercayaan warga negara terhadap partai politik. Ini terjadi berkaitan dengan tidak jelasnya garis ideologi partai, masih berperannya budaya "paternalistic", dan tidak dilaksanakannya pendidikan politik dan perpolitikan oleh partai politik.
\end{abstract}

Kata kunci: partai politik, partisipasi politik, status sosial ekonomi

\section{Pendahuluan}

Salah satu syarat untuk dapat memenuhi kriteria suatu Negara yang dianggap sebagai Negara hukum adalah adanya pemilihan umum yang bebas. Ketentuan Pasal 1 angka 1 UndangUndang Nomor 15 Tahun 2011 Tentang Pemilihan Umum menggariskan bahwa Pemilihan umum yang bebas dan tidak memihak dilakukan dari pusat sampai daerah. Pemilihan umum yang bebas dan tidak memihak sebagai ciri utama negara hukum, juga merupakan media dalam pembagian fungsi dan peran yang dilakukan. Rakyat sebagai subjek berperan penting dalam penentuan dan penyelenggaraan kehidupan bernegara. Indonesia sejak dibentuk oleh para pendiri, sangat berkepentingan untuk memenuhi syarat tersebut agar dapat diakui sebagai negara demokrasi dan negara hukum. Upaya tersebut justru kini bergulir cukup jauh, dimana tidak hanya Presiden bahkan Kepala Daerah Tingkat II ( kini Walikota dan Bupati) juga dipilih secara langsung melalui Pemilihan umum Legislatif dan Presiden/Wakil Presiden serta
Pemilihan Umum Kepala Daerah (Pemilukada). Dalam konteks ini, keterlibatan warga negara dalam kehidupan politik sangat nyata yang mempunyai hak dan kesempatan yang sama, akan tetapi berdasarkan penelitian penulis, pada pemilihan umum ataupun kepala daerah/Bupati Kabupaten Bandung, pemilihan umum tersebut tidak terlepas dari status sosial ekonomi (SSE) dan kualitas partai. Keragaman status sosial ekonomi masyarakat yang status sosial ekonomi belum banyak berperan, karena dengan status sosial ekonomi tinggi, masih terdapat masyarakat yang bersikap apatis pragmatis, dan begitu sebaliknya. Pendapat Damsar (2010: 200) bahwa "Status sosial ekonomi memiliki beberapa indikator yang digunakan untuk melakukan analisis tentang hubungan atau pengaruh, yaitu pendidikan, pekerjaan dan pendapatan/penghasilan." Hubungan dan pengaruh dalam penelitian ini adalah status sosial ekonomi yang berpengaruh terhadap partisipasi politik. Budaya politik yang berkembang pada suatu masyarakat berpengaruh pada 
keterlibatan mereka dalam kehidupan politik dan peran politik yang mungkin dilakukan sebagai warga negara.

Pemilihan Kepala Daerah (Pilkada) Kabupaten Bandung Periode 2010-2015 laksanakan sejalan dengan habisnya masa jabatan Bupati Obar Sobarna pada tanggal 5 Desember 2010. Pelaksanaan Pilkada Kabupaten Bandung dilaksanakan pada tanggal 29 Agustus 2010, diikuti oleh 8 (delapan) pasangan calon Bupati dan wakil Bupati periode 2010-2015, yang lolos verifikasi dan administrasi, dari sembilan pasangan cabupcawabup (bupati). Delapan yang lolos secara adminstratif dan sesuai dengan verifikasi KPU Kabupaten Bandung, 5 pasangan diusung oleh parpol dan 3 berasal calon perseorangan (independen). Ideologi yang dianut oleh suatu partai ataupun individu terlihat campur aduk berdasarkan data dari calon dan penggusung partai ampak nyata dalam unsur pengusung calon bupati. Deden Rumaji tidak didukung oleh partai amanat nasional (PAN) padahal secara institusional ang bersangkutan adalah kader dan fungsional PAN, karena quota PAN untuk mengusung calon sudah menetapkan pasangan Deding Ishak Siswanda. Pada Pilkada ini PAN berkolaborasi dengan Partai Persatuan Pembangunan (PPP), Partai Kebangkitan Bangsa (PKB) dan Partai Hati Nurani Rakyat (HANURA), Deding Ishak adalah fungsionaris dan kader elite partai golkar. Data yang ada juga menunjukkan bahwa Rusna Kosasih adalah fungsionaris dan kader elit partai golkar yang didukung oleh partai Indonesia demokrasi perjuangan (PDIP).

Jumlah Daftar Pemilih Tetap (DPT) dalam pemilihan bupati dan wakil bupati Kabupaten Bandung, mengalami perubahan menjadi 2.129.802 orang dari yang telah ditetapkan sebelumnya yaitu 2.126 .683 . Penambahan ini merupakan hasil penghitungan ulang, karena pengaduan masyarakat yang merasa sudah berhak sebagai pemilih tetapi ternyata tidak terdaftar. Selain itu, tingkat partisipasi politik pemilih di Kabupaten Bandung hanya mencapai angka 65\%, padahal target tingkat partisipasi pemilih pada Pemilihan Umum Kepala Daerah (Pilkada) di Kabupaten Bandung tahun 2010 yang dibuat oleh Komisi Pemilihan Umum Daerah (KPUD) Kabupaten Bandung harus mencapai $70 \%$ partisipasi pemilih. Oleh karena itu, pentingnya mengkaji peranan status sosial ekonomi dan kualitas partai dalam meningkatkan partisipasi politik warga negara.

Adapun rumusan masalah yang dikaji meliputi: (1)Bagaimana peranan status sosial ekonomi dalam meningkatkan partisipasi politik di Kabupaten Bandung dalam pemilihan Bupati tahun 2010?; (2) Bagaimanakah peranan kualitas partai politik dalam meningkatkan partisipasi politik di Kabupaten Bandung dalam pemilihan Bupati pada tahun 2010?; dan (3) Bagaimanakah peranan status sosial ekonomi dan kualitas partai terhadap partisipasi politik dalam pemilihan Bupati Bandung tahun 2010?. Penelitian ini dilakukan pada 200 responden melalui dengan pendekatan kuantitatif dengan metode survei. Penelitian ini juga diperkuat dengan pendekatan kualitatif untuk menjaring data dari masyarakat pemilih di Kabupaten Bandung. Tujuan umum dalam penelitian ini adalah untuk menggali, mengkaji, menyeleksi, dan mengorganisasikan informasi teore-tis dan empiris yang berkaitan dengan konseptualisasi status sosial ekonomi dan kualitas partai dalam meningkatkan partisipasi politik dalam pemilihan Bupati Bandung tahun 2010.

\section{Status Sosial Ekonomi Masyarakat dalam Meningkatkan Partisipasi Politik pada Pemilihan Bupati Bandung Tahun 2010}

Penelitian ini menemukan bahwa status sosial ekonomi berpengaruh langsung terhadap partisipasi politik dengan tingkat cukup masingmasing sebesar $22,75 \% ; 28,62 \%$ dan $0,35 \%$. Sisanya adalah sebesar $77,25 \%$; 71,38\%; dan $99,65 \%$ merupakan pengaruh dari variabel atau faktor lain yang tidak diamati.

Penelitian ini menemukan ternyata status pendidikan, pendapatan, dan perbedaan jenis pekerjaaan (nonpetani dibandingkan dengan petani) berperan dalam meningkatkan partisipasi politik masyarakat kabupaten Bandung dengan tingkat yang cukup. Maksudnya, masyarakat Kabupaten Bandung 2010 yang memiliki pendidikan dan pendapatan tinggi lebih berpartisipasi dalam pemilihan Bupati Bandung 2010 dibandingkan dengan yang memiliki pendidikan dan pendapatan yang rendah (pendidikan rata-rata lulusan SMA), serta perbedaan jenis pekerjaan memiliki kecenderungan pekerjaan non petani lebih berpartisipasi dalam pemilihan Bupati Kabupaten Bandung 2010 (banyaknya pemilih yang bekerja sebagai petani lebih sedikit daripada nonpetani).

Warga yang berstatus pendidikan tinggi lebih banyak mengerti dan mengetahui hak dan kewajibannya sebagai warga negara khususnya dalam bidang politik karena cenderung dalam kegiatan menimba ilmu dapat menambah wawasan serta cakrawala pemikiran sehingga semakin sadar terhadap pentingnya ikut dalam berpartisipasi meskipun tingkat partisipasinya tidak menjadi pemimpin politik dan aktivis politik, tetapi mengobrolkan dan diskusi tentang pemilukada, mengikuti kampanye, mendatangi Tempat Pemungutan Suara (TPS), menggunakan hak suara dalam pemilukada, serta mengikuti kegiatan dalam penghitungan suara. Dalam kenyataanya, orang yang memiliki kesadaran lebih tinggi akan 
berbanding lurus dengan tingkat partisipasinya. Warga negara yang berpendidikan tinggi semakin tinggi pengetahuan dan wawasan mengenai pemilukada karena lebih banyak informasi yang didapat baik melalui media elektronik maupun surat kabar sehingga bahan dalam diskusi ataupun obrolan semakin banyak. status sosial ekonomi itu umumnya berkaitan dengan status sosial ekonomi seseorang dalam keluarga yang ditandai oleh tingkat/jenjang pendidikan, status/jenis pekerjaan, dan tingkat penghasilan/pendapat. Status sosial ekonomi memiliki beberapa indikator yang digunakan untuk melakukan analisis tentang hubungan atau pengaruh, yaitu pendidikan, pekerjaan dan pendapatan/penghasilan (Damsar, 2010: 200).

Penelitian ini menemukan juga bahwa warga negara yang memiliki status pendidikan tinggi semakin banyak memperoleh informasi tentang seluk beluk kandidat atau partai politik yang mengusung melalui berbagai macam media. Akibatnya, terdapat warga negara/masyarakat yang memutuskan untuk tidak memilih dan apatis terhadap pemilihan Bupati Kabupaten Bandung 2010. Status pendidikan tinggi kurang/rendah berpartisipasi ataupun berpartisipasi pada level apatis karena berdasarkan informasi yang didapat kandidat tidak pantas menjadi Bupati sehingga berbeda dengan perspektif warga yang bersatus pendidikan tinggi.

Penelitian ini menemukan warga bersatus pendidikan tinggi dapat mengetahui bahwa dalam pemilukada telah terjadi money politic sehingga membuat warga berlatar belakang pendidikan tinggi kurang berpartisipasi politik dalam pemilukada bupati Kabupaten Bandung tahun 2010. Oleh karena itu, diperlukan peningkatan pendidikan bagi warga negara baik pendidikan formal, informal ataupun nonformal yang pada hakikatnya perlu dilengkapi dengan pendidikan politik dari partai politik secara berkesinambungan, continue, dan konsisten bagi semua warga tidak hanya terbatas pada konstituennya. Oleh karena itu, dapatlah disimpulkan sementara bahwa status sosial ekonomi berperan dalam meningkatkan partisipasi politik meskipun belum signifikan hal ini dikarenakan masih terdapat pemilih yang berpendidikan tinggi dan berpendapatan mapan kurang percaya terhadap partai politik dan pemilih yang memiliki pendidikan dan pendapatan rendah, serta pekerjaan yang kurang mapan lebih cenderung untuk memenuhi kebutuhan ekonomi terlebih dahulu daripada kehidupan politik.

\section{Kualitas Partai Politik dalam Meningkatkan Partisipasi Politik pada Pemilihan Bupati Bandung Pada 2010}

Berdasarkan data hasil penelitian yang dihitung secara statistik dan didukung oleh hasil wawancara dan dokumentasi, maka dapat diketahui bahwa kualitas partai berperan dalam meningkatkan partisipasi politik di Kabupaten Bandung pada pemilihan Bupati Bandung Tahun 2010, di mana kualitas partai terdiri atas pendidikan politik dimensi kognitif berperan dalam meningkatkan partisipasi politik dengan kategori cukup, yaitu 32,26\%.; pendidikan politik dimensi afektif 40,32\%; ideologi partai politik 28,72\%; dan pola kepemimpinan $46,65 \%$. Artinya, hubungan antara pendidikan politik dimensi afektif, pendidikan politik dimensi kognitif, ideologi partai politik, dan pola kepemimpinan partai dengan partisipasi politik memiliki kategori cukup atau memiliki hubungan positif dengan partisipasi politik.

Kualitas partai dalam penelitian ini terdiri dari pendidikan politik kognitif, pendidikan politik sikap, ideologi partai, dan pola kepemimpinan yang dapat berpengaruh dalam meningkatkan partisipasi politik masyarakat Kabupaten Bandung pada pemilihan Bupati tahun pada 2010. Partai politik merupakan salah satu kajian Pendidikan Kewarganegaraan karena salah satu isinya adalah tentang hubungan antarwarganegara dan hubungan antara warganegara dengan negara yang menyangkut warga negara, partai politik, dan organ negara khususnya di daerah yaitu terkait partisipasi politik masyarakat dalam pemilihan Bupati. Hal tersebut sesuai dengan hubungan warga negara Pendidikan Kewarganegaraan dalam pradigma baru dalam demokrasi yang memiliki tiga fungsi pokok; salah satunya adalah civic participation atau mendorong partisipasi warga negara (Sapriya dan Winataputra, 2007: 1.1).

Partisipasi merupakan ciri khas adanya modernisasi politik yaitu kegiatan yang dilakukan warga negara untuk terlibat dalam proses pengambilan keputusan dengan tujuan untuk mempengaruhi pengambilan keputusan yang dilakukan oleh pemerintah. Partisipasi politik warga negara perlu mendapat ruang yang luas, bukan hanya terbatas pada saat pemilu (partisipasi lima tahunan), akan tetapi juga dalam setiap perumusan, implementasi dan pertanggungjawaban kebijakan publik. Mekanisme dalam strukturformal keperintahan yang transparan, partisipatif, dan akuntabel sangat diperlukan untuk mejwujudkan kondisi tersebut. Dalam sebuah demokrasi yang kuat, partisipasi bukan sekedar mempertahankan kepentingan, melainkan merupakan suatu proses publik yang matang, yang tidak mengklaim suatu kebenaran melebihi apa yang disetujui secara konsensus oleh warga negara. Partisipasi politik lebih cenderung efektif pada aktivitas yang dilakukan oleh mereka yang memiliki kesempatan, kemampuan maupun kekuasaan dalam mempengaruhi keputusan publik sehingga partisipasi politik masyarakat kabupaten 
Bandung cenderung kurang efektif. Sebagian masyarakat Kabupaten Bandung karena kurang memiliki kesempatan tidak menjadi pejabat partai politik sehingga kemampuan ataupun tidak memiliki kekuasaan mempengaruhi keputusan publik. Pendapat Verba, Nie dan Kim dalam Gaffar (2006: 46), memaknai partisipasi politik sebagai:

Activities by private citizens that are more or less directly aimed at influence the election of governmental personnel and/or the action they take.

Partai politik merupakan sarana bagi warga negara untuk turut serta atau berpartisispasi dalam proses pengelolaan negara untuk negara yang menjadikan demokrasi sebagai sistem pemerintahan. Partai politik merupakan salah satu komponen penting untuk memastikan terselenggaranya kehidupan bernegara yang demokratis. Selain sebagai struktur kelembagaan politik yang anggotanya bertujuan mendapatkan kekuasaan dan kedudukan politik, partai politik merupakan wahana bagi penampungan aspirasi masyarakat. Peran tersebut merupakan implementasi nilai-nilai demokrasi, yaitu keterlibatan masyarakat untuk melakukan kontrol terhadap penyelenggaraan negara. Pendidikan kewarganegaraan dalam pengertian yang luas seperti citizenship education atau education for citizenship yang mencakup pendidikan kewarganegaraan di dalam lembaga pendidikan formal (dalam hal ini di sekolah dan dalam program pendi-dikan guru) dan di luar sekolah baik yang berupa program penataran atau program lainnya yang sengaja dirancang atau sebagai dampak pengiring dari program lain yang berfungsi memfasilitasi proses pendewasaan atau pematangan sebagai warganegara Indonesia yang cerdas dan baik program dari partai politik dengan salah satu fungsinya adalah wadah partisipasi politik warga negara Cogan (dalam dalam Budimansyah dan Winataputra, 2007: 10).

Pendidikan politik kognitif berpengaruh terhadap kesadaran partisipasi politik dengan tingkat sebesar $28,62 \%$, dengan pendidikan politik kognitif yang dimiliki warga negara menandai warga negara menjadi mengetahui konsep-konsep yang terkait dengan politik seperti demokrasi. Kompetensi PKn yang harus dimiliki warga negara yaitu civic knowledge. Kompetensi Kewarganegaraan yang harus dimiliki seorang warga negara yang pertama adalah pengetahuan kewarganegaraan karena agar menjadi warga negara yang cerdas dan dapat mempengaruhi kebijakan umum warga negara harus memiliki pengetahuan sebagai warga negara seperti mengikuti informasi terkini. Pengetahuan yang mendasar tertuang pada Pancasila dan UUD NRI 1945 khususnya mengenai sistem politik bangsa Indonesia dan struktur pemerintahannya, sehingga sangat diperkukan keterampilan intelektual mengetahui mana calon pemerintah daerah yang memiliki visi, misi dan program kerja yang pro rakyat. Warga negara hendaknya memahami bahwa melalui keterlibatan mereka dalam kehidupan politik dan civil society, mereka dapat membantu kualitas hidup di lingkungan sekitar mereka, masyarakat banyak dan seluruh bangsa. Jika mereka menginginkan suara-suara mereka didengar, mereka harus menjadi warga negara yang aktif dalam proses politik. Warga negara akan memiliki peluang lebih besar dalam mencapai tujuan-tujuan pribadi baik untuk dirinya sendiri, keluarga, maupun untuk kepentingan masyarakat, bangsa, dan negara bila mereka adalah warga negara yang berpengetahuan, efektif, dan bertanggungjawab.

Kegiatan partai politik kebanyakan hanya sebatas sosialisasi khususnya menjelang pemilihan umum dan dalam sosialisasi tujuan yang ingin dicapai hanya sebatas mendapatkan suara. Hasil temuan dalam penelitian iniditemukan Media-media yang digunakan partai politik ataupun kandidat masih belum mendidik warga negara seperti kampanye dengan dangdutan dan terdapat beberapa partai yang melakukan pelatihan itupun dibatasi hanya untuk pengurus dan waktunya sekali sebelum ada pemilu seperti yang diungkapkan seorang aktivis partai di Kecamatan Cikancung.

Ada sebagian masyarakat Kabupaten Bandung mengikuti kampanye dan mencoblos karena adanya perangsang untuk berpartisipasi. Hal tersebut diperkuat oleh pendapat Roosenberg dalam Upe (2008: 243,244) yang menyatakan bahwa:

salah satu faktor penyebab orang menghindari diri dari kehidupan politik adalah tidak ada perangsang untuk berpartisipasi dalam kehidupan politik.

Keterlibatan seseorang dalam aktivitas politik dikarenakan adanya motif tertentu yaitu keuntungan intrinsik seperti dorongan, dukungan, pengayoman, perhatian maupun ekstrinsik seperti uang, beras, minyak tanah, garam, semen, pengobatan dan lain-lain yang menguntungkan atau pertimbangan rasional pragmatis sehingga memunculkan kegiatan politik uang (money politic). Partisipasi politik masyarakat hanya karena perangsang yang merupakan cerminan masyarakat yang tidak demokratis dan tidak sesuai dengan aturan yang ada serta nilai kejujuran tidak ada. Antarpartai politik perlu adanya kesepakatan tentang batas-batas cost politic, yaitu dalam ukuran minimal pembuatan atribut kampanye seperti baliho, spanduk, kaos, iklan di TV dan Radio serta media cetak lainnya. Demikian juga pada saat penataan tempat kampanye yang eksklusif, mengundang artis dan tentu saja pengiringnya band terkenal, sound sistem yang memiliki suara 
yang bagus, tenda kampanye yang unik, juga memberikan makanan dan minuman kepada peserta yang hadir dalam suatu gelar kampanye.

Kenyataan pemberian materi dan uang sebenarnya sudah sulit dihindarkan karena anggapan umum sudah sepakat untuk menganggapnya sebagai suatu kewajaran, maka dianggap sebagai konsekwensi suatu pertandingan, sehingga tidak dianggap pelanggaran. Dengan demikian, dapatlah ditarik suatu definisi bahwa ongkos politik adalah keseluruhan biaya yang harus dikeluarkan oleh kandidat/aktivis politik dalam rangka pendapaian tujuan kegiatan politik tertentu. Agar antara money politics dengan ongkos politik menjadi jelas baik tindakan maupun kriterianya, sebaiknya partai politik dalam suatu daerah pemilihan umum mengadakan kesepakatan yang jelas, sehingga pengawasan Panwaslu memunyai dasar dan kekuatan yuridis yang jelas. Selain itu, ancaman sanksi atas pelanggaran ketentuan tersebut juga sudah sangat jelas adanya. Akan tetapi, jenis lain yang tidak kalah bahayanya dari money politics yaitu munculnya "shadow state" (William Reno dalam Faiz.M.Pai, 2011 http:// www.makepovertyhistory.org at 3:43 PM/) bahwa bentuk shadow state ini hadir dalam pola kekuasaan kepala daerah yang menjalankan pemerintahan dengan memberikan peran dan keuntungan sesuai kepentingan pemilik modal yang telah berjasa dalam mendukung pencalonannya.

Berdasarkan pendapat di atas para calon yang tidak memiliki dana yang mencukupi maka para calon akan didukung atau diberi modal oleh para pengusaha ataupun pemilik modal dengan tujuan apabila para calon menang maka kebijakan yang dibuat harus menguntungkan para pemilik modal. Oleh karena itu, apabila dilihat sekarang ini kebijakan-kebijakan yang dibuat oleh tidak sedikit pejabat lebih menguntungkan para pengusaha daripada warga negara miskin, dan inilah memunculkan adanya korupsi dari para pejabat karena untuk mengambalikan modal. Selain itu, banyak para calon kepala daerah menjadi tersandera dengan utang dan pinjaman modal masa lalunya, sehingga menimbulkan korupsi dan banyak terjadi kasus para calon yang tidak terpilih menjadi gila atupun bunuh diri. Jika tidak dengan cara korupsi konvensional, utang yang bertumpuk itu akan dibayar dengan program dan kebijakan yang pro capital sponsors (William Reno dalam Faiz.M.Pai, 2011 http://www.makepovertyhistory. org at 3:43 $P M /$ ).

Hal tersebut di atas diperkuat oleh pendapat Firmanzah (2008: 269) beranggapan kampanye politik diartikan oleh kandidat atau partai politik sebagai kampanye politik. Oleh karena itu, terlihat adanya pemahaman yang sempit tentang kampanye politik yang hanya menfokuskan diri pada periode kampanye Pemilu belaka. Usaha, dana, perhatian dan energi dipusatkan untuk mempengaruhi dan memobilisasi masyarakat pada saat menjelang pemilihan karena yang terpenting adalah hasil suara yang didapat tanpa melihat kepentingan bangsa seperti membantu dalam menyelesaikan masalah bangsa.

Apabila dikaji dari perspektif Pendidikan Kewarganegaraan, partisipasi politik yang didorong karena rangsangan tidak sesuai dengan tujuan PKn sendiri yang membentuk warga negara yang cerdas dan baik serta fungsi dalam paradigma baru PKn yaitu membentuk warga negara yang partisipatif dan demokratis karena cara-cara yang dilakukan oleh kandidat ataupun partai politik hanya sebatas kemenangan suara dengan berbagai cara tanpa melihat proses yang tidak memuat nilai-nilai demokrasi. Pendidikan Kewarganegaraan memiliki misi value based sehingga perilaku yang dilakukan kandidat ataupun partai politik dari perspektif PKn belum menanamkan nilai-nilai demokrasi dimana kehidupan politik tidak dibarengi oleh kesadaran terhadap hukum yang berlaku sehingga banyak terjadi perilaku-perilaku yang melanggar hukum. Pendidikan politik tentang ideologi politik berpengaruh terhadap partisipasi warga negara atau masyarakat. Penelitian ini menemukan bahwa ideologi politik berpengaruh dalam peningkatan partisipasi masyarakat Kabupaten Bandung dalam pemilihan Bupati sebesar 28,72\%. Ideologi yang dianut sebagian besar masyarakat kabupaten Bandung adalah ideologi nasionalis sebesar 40,5\%. Teori dialektika aksi Sewell (1988) dan teori strukturasi Giddens (1984) dalam Firmanzah (2008: 121) bahwa ideologi dianggap sebagai faktor utama bagi pemilih dalam menentukan partai yang akan dipilih dan sekaligus bisa berevolusi seiring perjalanan waktu.

Masyarakat Kabupaten Bandung secara turun temurun berbasis ideologi Golkar karena beranggapan Golkar memuat nilai-nilai yang dipercaya masyarakat tersebut. Partai Golkar yang berideologi nasionalis berada pada peringkat pertama dalam perolehan suara, peringkat kedua partai Demokrat yang ideologinya hampir sama yaitu nasionalis, padahal masyarakat tersebut daerah pesantren tetapi ideologi yang dianut sebagian besar bukan ideologi Islam modern ataupun Islam tradisional. Alasan masyarakt Kabupaten Bandung memilih partai Golkar karena lebih mapan nilai-nilai yang termuat Pancasila dan doktrin karya kekaryaan sebagai perbuatanperbuatan yang dilakukan secara sadar, terencana, sistematis, dan menyeluruh, untuk mendatangkan manfaat bagi rakyat. Karya kekaryaan adalah juga amal shalih dalam pengertian yang luas sebagaimana yang diajarkan agama.

Ketidakjelasan ideologi partai terlihat pada pasangan calon Bupati sendiripun menunjukkan adanya pengesampingan ideologi, nomor urut 
calon Bupati dan wakil Bupati Bandung Periode 2010-2015. Ideologi yang dianut itu campur aduk karena Deden Rukman, didukung oleh PAN padahal secara institusi orang Golkar, karena quota Golkar sudah terpenuhi. Fungsi ideologi adalah sebagai identitas yang dapat menyatukan golongan atau kelompok dan sebagai pembeda antarkelompok. Ideologi dapat digunakan untuk daya tawar kepada masyarakat dan melanggengkan ideologi politik yang menjadi latar belakang pendirian partai politik. Ideologi partai politik sangat menentukan partai apa dan kandidat yang seperti apa yang menurut pemilih dapat menyuarakan suara mereka. Di Kabupaten Bandung ideologi partai Golkar sangat kuat dalam diri pemilih karena sudah turun temurun dengan alasan nilai yang terkandung dalam partai Golkar yang nasionalis.).

\section{Peranan Status Sosial Ekonomi dan Kualitas Partai terhadap Partisipasi Politik Pada Pemilihan Bupati Bandung 2010}

Berdasarkan data hasil penelitian yang dihitung secara statistik, maka dapatlah diketahui secara keseluruhan bahwa sebesar $64 \%$ peningkatan partisipasi politik para pemilih Kabupaten Bandung diperankan oleh perubahan secara simultan dari variabel Struktur Ekonomi Sosial menyangkut tingkat pendidikan $\left(X_{1}\right)$, dan tingkat pendapatan $\left(X_{2}\right)$, Perbedaan Jenis Pekerjaan (dummy) dan kualitas partai menyangkut: Kognitif Politik $\left(X_{3}\right)$, Pendidikan politik dimensi afektif $\left(X_{4}\right)$, Ideologi Partai Politik $\left(X_{5}\right)$ dan Pola Kepemimpinan $\left(\mathrm{X}_{6}\right)$.

Pada masyarakat Kabupaten Bandung khususnya sebagai pemilih ditemukan pendidikan, dan pekerjaan yang tinggi berpengaruh terhadap partisipasi politik masyarakat kabupaten Bandung tetapi tidak berati. Maksudnya, masyarakat Kabupaten Bandung 2010 yang memiliki pendidikan, pekerjaan dan pendapatan tinggi ini sebagaian besar kurang berpartisipasi dalam pemilihan Bupati Bandung 2010 daripada yang memiliki pendidikan, pekerjaan dan pendapatan yang rendah. Alasan yang ditemukan dari hasil penelitian pada orang yang berpendidikan tinggi informasi yang didapat mengenai seluk beluk kandidat atau partai politik yang mengusung semakin banyak melalui berbagai macam media mengakibatkan warga negara/masyarakat tersebut memutuskan untuk tidak berpartisipasi dan apatis terhadap kegiatan politik seperti kampanye dan pemilihan Bupati Kabupaten Bandung 2010 karena menurut mereka kandidat tersebut tidak pantas menjadi Bupati sehingga beranggapan kalau memilih akan membuat keputusan yang salah yang membuat daerahnya ke depan menjadi tidak mengalami perubahan yang maju dan akan menambah permasalahan bangsa. Pendapat Damsar (2010: 201) bahwa bisa terjadi orang yang berpendidikan rendah memiliki partisipasi lebih tinggi daripada yang berpendidikan rendah kaena informasi yang didapat orang berpendidikan tinggi lebih banyak sehingga perspektifnya tidak ada satupun yang sesuai perspektifnya.

Selain itu, masyarakat yang berpendidikan tinggi menjadi apatis artinya partisipasinya tidak berarti. karena anggapan mereka pemilihan secara langsung dan sampai dua kali putaran Bupati Bandung hanya menghabiskan uang negara dengan sia-sia dimana demokrasi yang akan dibangun tidak tercapai karena money politic tetap berjalan sehingga rasionalnya pemilih seperti itu membuat mereka apatis. Hal tersebut berbeda dengan pendapat Rose dalam Mas'oed dan McAndrew (1982: 110) yang menyatakan bahwa makin banyak pendidikan yang didapat seseorang makin besar kemungkinannya bahwa ia menyokong partai politik yang bersifat terpelajar; memelihara rasa tertarik pada pada politik; aktif dalam politik.

Penelitian ini menemukan bahwa masyarakat Kabupaten Bandung khususnya sebagai pemilih ternyata pendidikan, dan pekerjaan berpengaruh terhadap partisipasi politik masyarakat kabupaten Bandung. Maksudnya, masyarakat Kabupaten Bandung 2010 yang memiliki pendidikan, pekerjaan dan pendapatan tinggi ini berpartisipasi dalam pemilihan Bupati Bandung 2010 daripada yang memiliki pendidikan, pekerjaan dan pendapatan yang rendah. Tingginya status sosial ekonomi seseorang mengakibatkan tingginya partisipasi politik orang tersebut. Warga atau pemilih Kabupaten Bandung yang sebagian besar lulusan SMA masih ada kurang berpartisipasi politik dalam pemilihan Bupati Bandung Tahun 2010 karena selain banyak pengetahuan yang dimiliki tentang pemilihan Bupati yang membuat berbeda pandangan sehingga tidak berpartisipasi seperti mengetahui kandidatnya tidak sesuai yang diharapkan pribadi pemilih.

Selanjutnya, selain itu juga perbedaan jenis pendapatan selain karena waktu yang membuat ada sebagian pemilih masih kurang berpartisipasi karena alasan budaya politik dimana bagi petani berpartisipasi akan mendapatkan bantuan untuk pertaniannya ataupun karena motif perangsang baik imateriil maupun materiil yang berdasarkan pertimbangan rasional pragmatis, seperti mendapat uang lelah dalam kampanye, ada pembagian pupuk gratis yang menggiring pada money politic. Pemilih yang memiliki pedapatan tetap cenderung untuk berpartisipasi karena sudah tercukupinya kebutuhan ekonominya.

Partisipasi yang didukung karena perangsang materi serta akan menimbulkan rasa tidak peduli terhadap bangsa ataupun antipati terhadap politik yang berlebihan ini akan mengakibatkan hilangnya rasa cinta tanah air dan 
rasa nasionalisme bangsa Indonesia. Oleh karena itu, para pelaku politik dan partai politik harus memberikan pendidikan politik kepada warga negara/masyarakat. Partai politik berfungsi sebagai sarana sosialisasi politik agar masyarakat belajar mengenali sistem politiknya yang dapat dilakukan melalui berbagai cara yaitu media massa, ceramah-ceramah, penerangan, kursus kader, penataran dan sebagainya. Sisi lain dari fungsi sosialisasi politik adalah upaya menciptakan citra bahwa ia memperjuangkan kepentingan umum. Upaya penciptan citra penting apabila dikaitkan dengan tujuan partai politik untuk menguasai pemerintah melalui kemenangan dalam pemilihan umum. Partai politik dapat menjalankan fungsi sosialisasinya yakni mendidik aggota-anggotanya menjadi manusia yang sadar akan tanggung jawabanya sebagai warga negara menempatkan kepentingan sendiri di bawah kepentingan nasional.

\section{Simpulan}

Status sosial ekonomi berperan dalam meningkatkan partisipasi politik meskipun belum signifikan. Hal ini disebabkan masih terdapat pemilih yang berpendidikan tinggi dan berpendapatan mapan kurang percaya terhadap partai politik dan pemilih yang memiliki pendidikan dan pendapatan rendah serta pekerjaan yang kurang mapan lebih cenderung untuk memenuhi kebutuhan ekonomi terlebih dahulu daripada kehidupan politik. Kualitas partai politik yang terdiri dari pendidikan politik koginitif, pendidikan afektif, ideologi partai, dan pola kepemimpinan berperan secara berarti dalam meningkatkan partisipasi politik di Kabupaten Bandung pada pemilihan Bupati tahun 2010 pada tingkatan cukup, sehingga partai politik dapat dijadikan sebagai sarana program PKn di masyarakat yang sinergis dan berkesinambungan untuk membentuk warga negara yang baik dan cerdas (berpartisipasi dengan penuh tanggung jawab) demi tercapai kepentingan nasional dan tujuan nasional. Status sosial ekonomi dan kualitas partai berperan berarti secara simultan dalam meningkatkan partisipasi politik pada pemilihan Bupati Kabupaten Bandung tahun 2010, dengan demikian diperlukan peningkatan status sosial ekonomi dan kualitas partai secara simultan.

Bagi Pemerintah pusat dan pemerintah daerah bukan hanya pemenang pemilu harus melakukan kebijakan secara menyeluruh terkait peningkatan partisipasi politik warga negara yang didukung dengan pendidikan politik baik mellaui jalur formal maupun nonformal.

Bagi partai politik agar melakukan peran dan fungsinya sebagaimana ketentuan Undang-Undang sehingga partai memiliki kualitas dan berperan aktif dalam upaya meningkatkan partisipasi warga negara, adapun upaya yang harus antara lain sebagai berikut: (a) Partai politik harus melakukan pendidikan politik baik dari aspek kognitif dan sikap secara kontinue tidak hanya pada waktu menjelang pemilu ataupun pemilukada yang selama ini pendidikan politik berhenti setelah masyarakat memberikan suara; (b) Ideologi partai politik yang dianut oleh setiap partai politik ataupun setiap warga negara (caleg dan pemilih) itu harus berdasarkan ideologi Pancasila dan konsisten terhadap satu ideologi yang digunakan tidak seperti sekarang ini, ideologi yang dianut adalah campur aduk; (c) Pola kepemimpinan partai politik sebaiknya setiap partai memiliki kekhasan meskipun berpola demokrasi sehingga masyarakat lebih jelas dalam memantapkan pilihan partai dan pilihan calon-calon yang diusung dari partai; (d) Adanya kesepakatan antar partai politik untuk tidak melakukan pembodohan dan penipuan kepada masyarakat seperti money politic dan adanya shadow state; (e) Tidak memberikan janji-janji fantastis di luar batas kewajaran untuk dapat dipenuhi; (f) Meningkatkan kredibilitas sehingga tidak menyebabkan masyarakat pemilih bersikap apatis, karena hal ini dapat merusak nasionalisme, cinta tanah air Indonesia, dan pada gilirannya mengancam kepentingan nasional.

Bagi dunia pendidikan, khususnya Program Studi Pendidikan Kewarganegaraan hendaknya dapat mengantisipasi kondisi tersebut di atas dengan melakukan penyusunan kurikulum PKn dan pembekalan terhadap pengajar mulai dari tingkat dasar sampai perguruan tinggi tidak hanya secara teori, akan tetapi harus dilengkapi dengan perbandingan aplikasi yang terjadi di lapangan.

Bagi peneliti selanjutnya, penelitian ini membuka kesempatan untuk melakukan penelitian lanjutan dengan menggunakan metode kualitatif tentang partisipasi masyarakat yang muncul karena rangsangan materi yang menyangkut status sosial ekonomi, pola kepemimpinan partai politik, dan masa depan nasionalisme bangsa Indonesia.

\section{Daftar Pustaka}

Almond, G dan V. Sidney. (1990). Budaya Politik Tingkah Laku Politik dan Demokrasi di Lima Negara. Jakarta: Bina Aksara.

Brownhill, Robert \& Smart, Patricia. (1989). Political Education. London and new York. Routledge.

Budiardjo, Miriam. (2008). Dasar-Dasar Ilmu Politik. Jakarta. Gramedia Pustaka Utama.

Budiardjo, M. (1982). Partisipasi dan Partai Politik. Jakarta: Gramedia.

Budiardjo,M. (1985). Aneka Pemikiran tentang Kuasa dan Wibawa. Jakarta: Pustaka Sinar Harapan. 
Budimansyah, D. dan Winataputra, S. U. (2007).Civic Education Konteks ,Landasan, Bahan Ajar, dan Kultur Kelas. Bandung: Program Studi Pendidikan Kewarganegaraan Sekolah Pascasarjana Universitas Pendidikan Indonesia.

Brownhill, Robert \& Smart, Patricia. (1989). Political Education. London and new York. Routledge.

Cogan, J. J dan Derricott, R., (1998). Citizenship for the 21st century: An International perspective on Education. London: Kogan Page.

Creswell, J.W. (1998). Research Design Qualitative \& Quantitative Approach. London: Publication.

Creswell, J.W. (2010). Research Design Qualitative \& Quantitative Approach.Penerjemah Achmad Fawaid. Yogyakarta: Pustaka Pelajar.

Damsar. (2010). Pengantar Sosiologi Politik.Jakarta; Kencana Premedia Goup.

Duverger, M. (1967). Political Parties: Their Organization and Activity in The Modern State. London: Methuen.

Evans, Kevin Raymond. (2003). Sejarah Pemilu dan Partai Politik di Indonesia. Jakarta: PT Arise Consultancies.

Faulk, Keith. (2010). Sosiologi Politik Pengantar Kritis. Bandung. Nusa Media.

Feith, H. (1968). The Decline of Constitutional Democracy in Indonesia. Ithaca, New York: Cornel University Press.

Firmanzah. (2008). Mengelola Partai Politik. Jakarta. Yayasan Obor Indonesia.

Freire, Paulo. (2007). Politik Pendidikan Kebudayaan, Kekuasaan Dan Pembebasan. Yogyakarta. Pustaka Pelajar.

Gaffar, Afan. (2006). Politik Indonesia. Yogyakarta. Pustaka Pelajar.

Huntington, Samuel P, dan J. Nelson. (1994). Partisipasi Politik di Negara Berkembang. Jakarta: Rineka Cipta.

Huntington, Samuel. (2003). Tertib politik Ditengah Pergeseran Kepentingan Massa. Jakarta. Rajagrafindo Persada.

Kantaprawira, R. (1983). Sistem Politik Indonesia, Suatu Model Pengantar. Bandung: Sinar Baru.

Kelly, AV. (1995). Education And Democracy Principles And practices. London. Paul Chapman Publishing Ltd.

Marshad, Dhurorudin. (2008). Akar konflik Politik Islam di Indonesia. Cetakan ke-1 Jakarta; Pustaka Al Kautsar.

Magnis-Suseno, F. (1994) Etika Politik, Prinsip- prinsip Moral Dasar Kenegaraan Modern. Jakarta: Gramedia Pustaka Utama.

Mas'oed \& MacAndrews. (2003) Perbandingan Sistem Politik. Yogyakarta. Gadjah Mada University Press.

Nazsir. Nasrullah dan Amril Ghaffar Sunny. (2004) Partai Politik, Partisipasi Politik dan Pendidikan Politik. Bandung: PPS FISIP UNPAD.

Quigley, C.N., Buchanan, Jr. J. H., Bahmueller, C.F. (1991). Civitas: A Frame Work for Civic Education. Calabasas: Center for Civic Education.

Rush, Michael dan Philip Althoff. (1986). Pengantar Sosiologi Politik. Jakarta:PT. Raja Grafindo Persada.

Sapriya \& Winataputra. (2007). Materi dan Pembelajaran PKn SD. Jakarta: UT

Sanit, A. (1985). Swadaya Politik Masyarakat, Telaah tentang Keterkaitan Organisasi Masyarakat, Partisipasi Politik dan Pertumbuhan Hukuk dan Hak Asasi. Jakarta: Rajawali.

Sastroatmodjo, S. (1995). Perilaku Politik. Semarang: IKIP.

Soekanto S., (2005). Pribadi dan Masyarakat Suatu Tujuan Sosiologi. Bandung: Institut Teknologi Bandung.

Sudjana. (1992). Metoda Statistika. Bandung: Tarsito.

Sugiyono. (2005). Statistik untuk Penelitian. Bandung: CV Alfabeta

Sulistyo, Hermawan. (2003). Politik Pemilu di Indonesia: Jalan Berliku Menuju Demokrasi. Jakarta: Pensil-324.

Sumbu, Sell dan dkk. (2010). Kamus Umum Politik dan Hukum.Jakarta; Jala Permata Aksara.

Surbakti, Ramlan. (2010). Memahami Ilmu Politik. Jakarta. PT. Gramedia

Upe, Ambo. (2008). Sosiologi Politik Kontemporer: Kajian tentang Rasionalitas perilaku Politik pemilih di Era Pemilihan Kepala Daerah secara Langsung. Jakarta; Prestasi Pustakarya.

Yulisanti.A.I., (2000), Status Sosial Ekonomi dan Prilaku Konsumtif Kelas Menengah Baru.Yogyakarta: APMD. (http:// eprints.undip.ac.id/17736/1/ Wiji__Lestarini.pdf).

\section{Undang-Undang}

Undang-Undang Nomor 15 Tahun 2011 Tentang Pemilihan Umum.

Undang-Undang Nomor 32 Tahun 2004 Tentang Pemerintahan Daerah.

William Reno dalam Faiz.M.Pai, 2011 http:// www.makepovertyhistory.org at 3:43 PM/). 